Jurnal Akuntansi dan Investasi, Vol. 18 No. 1, Hlm: 102-118, Januari 2017

Artikel ini tersedia di website: http://journal.umy.ac.id/index.php/ai

DOI: $10.18196 /$ jai.18163

\title{
Determinan Kemampuan Auditor dalam Mendeteksi Kecurangan
}

Rudy Suryanto*; Yosita Indriyani; Hafiez Sofyani

Program Studi Akuntansi Universitas Muhammadiyah Yogyakarta, D.I. Yogyakarta, Indonesia

\begin{tabular}{l}
\hline A R T I C L E I N F O \\
\hline Article history: \\
received 15 Nov 2016 \\
revised 6 Des 2016 \\
accepted 13 Des 2016 \\
Keywords: \\
Experience; Workload; \\
Professional Skepticism; \\
Personality Type NT; \\
Ability to Detect Fraud \\
\hline
\end{tabular}

\begin{abstract}
A B S T RACT
This study aims to examine the influence of experience, workload, profesional skepticism, and personality type NT (Intution-thinking) toward the ability to detect fraud of auditors. The intensive search using the Rasch model approach developed by George Rasch with the involvement of auditors working in Yogyakarta and Surakarta as the study sample. This study fiund that the auditor's experience and personality type affect the auditor's ability to detect fraud. While the workload and profesional skpetisme auditor assessed not affect the auditor's ability to detect fraud. More detailed results of this study are presented in this paper.
\end{abstract}

(c) 2017 JAI. All rights reserved

\section{PENDAHULUAN}

Maraknya kasus kecurangan pelaporan yang terjadi akibat adanya kerjasama "hitam" anatara perusahaan besar dan auditor eksternal (pemeriksa) memunculkan inisiasi oleh para akuntan, baik praktisi maupun akademisi, untuk disusunnya standar audit baru yang disebut ISA (International Standard on Auditing) (Sari dan Rustiana, 2016). ISA menekankan pada audit berbasis risiko, principles-based standard, berpaling dari model sistematis, kearifan profesional dan konsekuensinya, pengendalian internal, dan those change with governance. Ciri yang paling menonjol dari ISA adalah penekanan terhadap aspek resiko. Penilaian risiko diatur dalam ISA 315 yang meliputi: 1) risiko bisnis yang relevan dengan tujuan pelaporan keuangan; 2) estimasi berapa signifikannya risiko; 3) besarnya potensi terjadinya resiko; dan 4) tindakan untuk menangani risiko (Tuanakota,2013). Selain basis risiko, ISA juga menekankan perubahan mendasar pada standar berbasis prinsip (principles-based standard). Sehingga pemakai standar tidak terpaku pada aturan yang cenderung kaku dan terkadang tidak sesuai dengan situasi yang sedang dihadapi. Permasalahan audit dari satu klien dengan klien lain tidak tentu sama sehingga dengan basis prinsip, auditor dapat mengatasi suatu situasi dan kondisi dengan prinsip-prinsip bukan aturan.

Akan tetapi, megacu pada kasus manipulasi pelaporan keuangan, hal semacam itu tidak hanya dapat terjadi karena adanya kerjasama "hitam" antara auditor dengan auditan, tetapi juga karena gagalnya auditor dalam mendeteksi kecurangan. Salah satu faktor yang mempengaruhi kegagalan auditor dalam mendeteksi kecurangan (fraud) yaitu kompetensi teknis yang terkendala (Tuanakotta, 2013). Kompetensi teknis yang terkendala dikarenakan tingkat pengetahuan, pengalaman, dan independensi auditor yang masih lemah (Koroy, 2009). Faktor lain yang menyebabkan kegagalan auditor pada penelitian Beasley et al., (2001) didasarkan pada AAERs (Accounting and Auditing Releases) berkaitan dengan rendahnya tingkat skeptisme profesional yang dimiliki oleh auditor (Carpenter et al., 2011), berlebihannya beban kerja auditor (Nasution, 2012), dan karakteristik kepribadian dari seseorang auditor (Noviyanti, 2008). Mengacu pada konsep MyersBriggs Type Indicators (MBTI), terdapat empat pasang preferensi manusia, yaitu extraversion dan introversion, sensing dan intuition, thinking dan feeling, serta judging dan perceiving. Masingmasing preferensi memiliki ciri yang berbeda-beda. Ciri yang berbeda menyebabkan perbedaan dalam individu mengembangkan sikap untuk menyikapi suatu kondisi (Tesser 1993; Petty et al., 1997; Noviyanti, 2008).

Berangkat dari berbagai argumentasi yang dipaparkan di atas, maka penelitian ini akan meneliti pengaruh variabel beban kerja, pengalaman, skeptisme profesional, dan tipe kepribadian terhadap kemampuan auditor dalam mendeteksi 
kecurangan dilihat dari sudut pandang teori perilaku yang direncanakan (Fishbein dan Ajzen, 1974; 1975; Ajzen dan Fishbein, 2005; Januarti (2011) dan konsep power distance (Hofstede, 2011). Penelitian ini didasarkan pada diterapkannya standar baru dalam audit yaitu ISA yang menekankan auditor untuk menggunakan kearifan profesional khususnya dalam mendeteksi kecurangan. Perbedaan penelitian ini dengan penelitian sebelumnya (Noviyanti, 2008; Carpenter et al., 2011; Nasution, 2012) adalah penelitian ini dilakukan di lokasi yang berbeda, yakni dengan melibatkan auditor di Yogyakarta dan Surakarta. Sedangkan kebaharuan dari penelitian ini adalah analisis data yang dijalankan menggunakan pendekatan Rasch Model.

Rasch model merupakan alat analisis yang dapat menguji validitas dan reliabilitas data serta menguji kesesuaian person dan item secara simultan. Rasch model mampu memberikan skala linear dengan interval yang sama, melakukan prediksi terhadap data yang hilang, memberikan estimasi yang tepat, mendeteksi ketidaktepatan model, serta menghasilkan pengukuran yang replicable (Suminto, 2013). Keunggulan Rasch model dibanding model lain adalah kemampuan melakukan prediksi terhadap data yang hilang, yang didasarkan pada pola respon yang sistematis. Model lain memperlakukan data yang hilang dengan nilai nol, sedang Rasch menghasilkan kemungkinan terbaik dari data yang hilang. Pendekatan model ini diharapkan memiliki keakuratan yang lebih baik dalam pengukuran variabel, sehingga menghasilkan simpulan penelitian yang juga lebih baik.

Penelitian ini juga memperbaharui penelitian Noviyanti (2008) yang menggunakan pendekatan eksperimen dalam pengujian hubungan tipe kepribadian dengan kemampuan mendeteksi kecurangan. Penelitian model eksperimen cenderung kuat pada aspek validitas internal tetapi lemah pada aspek validitas eksternal (Nahartyo, 2012; Sofyani dan Pramita, 2013; Rahma dan Yulianti, 2016). Sementara, penelitian ini menggunakan pendekatan survei guna menemukan validitas eksternal atau kemampuan generalisasi hasil riset yang lemah dari penelitian Noviyanti (2008) tersebut. Kebaharuan lainnya adalah, penelitian ini dilakukan di Kantor Akuntan Publik (KAP) yang ada di kota Yogyakarta dan Surakarta yang notabene merupakan kantor akuntan publik berskala kecil. Aspek menarik dari obyek ini adalah adanya dugaan rendahnya isu skeptisme dan kaitannya dengan kemampuan auditor dalam upaya mendeteksi kecurangan yang disebabkan oleh KAP yang lebih berorientasi pada proyek pekerjaan dibandingkan orientasi profesionalisme.

\section{TINJAUAN LITERATUR DAN PERUMUSAN HIPOTESIS}

\section{Teori Perilaku yang Direncanakan}

Ajzen (1991) dalam pandangannya mengenai konsep teori perilaku yang direncanakan (Theory of Planned Behavior) mengasumsikan bahwa manusia biasanya akan berperilaku pantas (behave in a sensible manner) sesuai dengan apa yang diinginkan lingkungannya. Tujuan dan manfaat teori ini dalam konteks penelitian ini adalah untuk meramalkan dan memahami pengaruh-pengaruh motivasi perilaku, baik kemauan individu itu sendiri maupun bukan kemauan dari individu tersebut.

Teori perilaku yang direncanakan, menurut Januarti (2011), memiliki fungsi dari tiga dasar determinan. Pertama, terkait dengan sikap dasar seseorang, contohnya adalah sikap seseorang terhadap intuisi, orang lain, atau obyek. Teori ini dapat menjelaskan bahwa sikap dasar atau kepribadian seseorang dapat terbentuk atas respon seseorang tersebut terhadap lingkungan, objek, dan intuisi. Berkaitan pula dengan penelitian ini, sikap skeptisme yang ditunjukkan auditor merupakan suatu sikap dalam menghadapi suatu kasus atau penugasan audit yang diberikan. Selain itu, jumlah beban dalam hal ini beban penugasan atau audit yang ditanggung seseorang juga akan mempengaruhi bagaimana ia akan bersikap. Kedua, menggambarkan pengaruh sosial yang disebut norma subjektif. Ketiga, berkaitan dengan isu kontrol. Faktor ini berkaitan dengan masa lalu dan persepsi seseorang terhadap seberapa sulit untuk melakukan suatu perilaku, contohnya adalah pengalaman audit dalam melakukan prosedur audit dalam penugasan auditnya.

\section{Beban Kerja dan Kemampuan Mendeteksi Kecurangan}

Beban kerja (workload) adalah jumlah pekerjaan yang harus dilakukan oleh seseorang. Setiawan dan Fitriany (2011) menyebutkan beban kerja auditor dapat dilihat dari banyaknya jumlah klien yang harus ditangani oleh seorang auditor atau terbatasnya waktu auditor untuk melakukan proses audit. Beban kerja seorang auditor bia- 
sanya berhubungan dengan busy season yang pada umumnya terjadi pada kuartal pertama awal tahun. Penyebab terjadinya busy season dari auditor adalah karena banyaknya perusahaan yang memiliki tahun fiskal yang berakhir pada bulan Desember. Menurut Nasution (2012) kelebihan pekerjaan pada saat busy season akan mengakibatkan kelelahan dan ketatnya time budget bagi auditor sehingga akan menghasilkan kualitas audit yang rendah. Dari penelitian Nasution (2012) ditemukan beban kerja berpengaruh negatif pada skeptisme profesional.

Pada konteks pendeteksian kecurangan, banyaknya beban kerja juga diduga berpengaruh negative terhadap kemampuan auditor dalam mendeteksi kecurangan. Hal ini sejalan dengan temuan Murtisari dan Ghozali (2006) sebagaimana dikutip Nasution (2012) yang menjelaskan bahwa beban pekerjaan dapat mengakibatkan menurunnya kepuasan kerja dan kinerja auditor. Penelitian Setiawan dan Fitriany (2011) menemukan beban kerja auditor berpengaruh negatif terhadap kualitas audit. Hasil-hasil penelitian tersebut mengindikasikan bahwa beban kerja yang semakin meningkat akan menurunkan kemampuan auditor dalam mendeteksi kecurangan atau kesalahan yang dilakukan manajemen karena kelelahan sehingga berakibat pada hasil audit yang rendah. Berdasarkan hasil penelitian sebelumnya, diduga semakin banyak beban kerja yang ditanggung, tidak akan meningkatkan kemampuan dalam mendeteksi kecurangan. Sehingga diturunkan hipotesis pertama, yaitu:

H1: Beban kerja berpengaruh negatif terhadap kemampuan auditor dalam mendeteksi kecurangan.

\section{Pengalaman dan Kemampuan Mendeteksi Kecurangan}

Pengalaman menjadi indikator penting bagi kualifikasi profesional seorang auditor (AU Seksi 110 paragraf 04) (Nasution, 2012). Pengalaman audit adalah pengalaman yang diperoleh auditor selama melakukan proses audit laporan keuangan baik dari segi lamanya waktu maupun banyaknya penugasan yang pernah ditangani menurut Suraida (2005). Auditor yang telah memiliki banyak pengalaman tidak hanya akan memiliki kemampuan untuk menemukan kekeliruan (error) atau kecurangan (fraud) yang tidak lazim yang terdapat dalam laporan keuangan tetapi juga auditor tersebut dapat memberikan penjelasan yang lebih akurat terhadap temuannya tersebut dibandingkan dengan auditor yang masih dengan sedikit pengalaman menurut Libby dan Frederick (1990) sebagaimana dikuti Nasution (2012).

Pengalaman auditor akan semakin berkembang dengan bertambahnya pengalaman audit, adanya diskusi mengenai audit dengan rekan sekerja, dan dengan adanya program pelatihan dan penggunaan standar. Perkembangan moral kognitif seseorang diantaranya sangat dipengaruhi oleh pengalaman (Nasution, 2012). Oleh sebab itu, pengalaman kerja dipandang sebagai suatu faktor yang penting dalam memprediksi kinerja auditor (Januarti, 2011).

Penelitian Noviyani (2002) yang didukung oleh penelitian Tirta dan Sholihin (2004) dan Nasution (2012) menemukan auditor yang berpengalaman akan memiliki pengetahuan tentang kekeliruan dan kecurangan yang lebih banyak sehingga akan menghasilkan kinerja yang lebih baik dalam mendeteksi kasus-kasus kecurangan dibandingkan dengan auditor yang tidak berpengalaman. Berdasarkan hasil penelitian sebelumnya, diduga terdapat pengaruh positif antara pengalaman dengan kemampuan mendeteksi kecurangan, yaitu semakin berpengalaman seorang auditor maka semakin meningkat kemampuan dalam mendeteksi kecurangan. Sehingga diperoleh hipotesis kedua sebagai berikut:

H2: Pengalaman audit berpengaruh positif terhadap kemampuan auditor dalam mendeteksi kecurangan.

\section{Skeptisme dan Kemampuan Mendeteksi Kecurangan}

Skeptisme profesional (professional skepticism) adalah sikap perilaku (attitude) yang sarat pertanyaan dalam benak (quetining mind), waspada (being alert) pada keadaan-keadaan yang mengindikasi kemungkinan salah saji karena kesalahan (error) atau kecurangan (fraud) dan penilaian yang kritis (critical assessment) terhadap bukti. (Tuanakotta, 2013). Pendeteksian kecurangan mengharuskan auditor mengumpulkan bukti-bukti yang cukup dan relevan. Maka dari itu, seorang auditor harus berpikir kritis dalam pengumpulan dan pemahaman bukti-bukti audit. Fullerton dan Durtschi (2004) menemukan bahwa auditor dengan skeptisme yang tinggi akan meningkatkan kemampuan mendeteksinya dengan cara mengembangkan pencarian informasiinformasi tambahan bila dihadapkan dengan gejala-gejala kecurangan. Berangkat dari argumentasi di atas, maka diduga semakin tinggi sikap 
skeptisme yang dimiliki auditor maka semakin tinggi pula tingkat kemampuan dalam mendeteksi kecurangan.

Namun demikian, pada konteks penelitian ini yang dilakukan di kota Yogyakarta dan Surakarta, yang notabene masuk dalam kawasan Jawa bagian tengah dimana auditor mayoritas berasal dari suku Jawa beretnis Jawa halus yang masih memiliki adab keraton yang kuat, maka skeptisme auditor dari etnis Jawa halus ini bisa saja termitigasi oleh karakteristik dari etnis tersebut yang senantiasa mengedepankan keharmonisan hubungan masyarakat. Hofstede (2001) menilai fenomena kuatnya adab keraton di Jawa bagian tengah ini, selanjutnya memunculkan apa yang disebut dengan power distance, dan berikutnya mempengaruhi sikap orang suku Jawa bagian tengah menjadi lebih sungkan dan menjaga keharmonisan (Prayudi dan Basuki, 2014). Sikap semacam ini berkemungkinan memunculkan rendahnya skeptisme profesional auditor karena auditor dari suku Jawa halus lebih mengedepankan keharmonisan hubungan dibandingkan tuntutan profesionalisme. Oleh karenaya, meskipun auditor memiliki skeptisme profesional, namun hal itu tidak dimunculkan demi menjaga hubungan baik antara auditor dan auditan. Berangkat dari argumentasi tersebut, maka pada konteks penelitian ini hipotesis yang dirumuskan adalah sebagai berikut:

H3: Skeptisme profesional tidak berpengaruh terhadap kemampuan auditor dalam mendeteksi kecurangan.

\section{Tipe Kepribadian NT (Intuition and Thinking) dan Kemampuan Mendeteksi Kecurangan}

Penelitian Noviyanti (2008) menemukan bahwa auditor dengan tipe kepribadian ST (Sense and Thinking) dan NT (Intuition and Thinking) adalah auditor yang memiliki skeptisme profesional yang lebih tinggi dibandingkan dengan auditor dengan tipe kepribadian lainnya. Skeptisme profesional yang tinggi akan memiliki kemampuan mendeteksi kecurangan yang tinggi. Kepribadian dengan tipe kombinasi ST dan NT merupakan tipe yang cenderung logis dalam mengambil keputusan karena mempertimbangkan fakta-fakta yang ada. Tipe kombinasi NT cenderung menekankan pola, konteks, dan hubungan dengan data yang meragukan dan tidak meyakinkan dimana pada kondisi tersebut auditor dituntut harus menebak-nebak makna dari data tersebut secara intuitif, dan selanjutnya digunakan sebagai dasar untuk menggali fakta dengan logika dan analisis yang obyektif serta kritis dalam situasi dimana keputusan harus diambil (Tuanakotta, 2013). Pada konteks audit, kecurangan umumnya bersifat sistematis atau memiliki pola, terkadang tidak meyakinkan, sehingga untuk menggalinya diperlukan logika analisis yang obyektif dan kritis. Berdasarkan konsep tersebut, maka diduga ada pengaruh tipe kepribadian kombinasi NT yang ada pada diri auditor terhadap kemampuan auditor tersebut dalam mendeteksi kecurangan. Berangkat dari argumentasi tersebut, maka hipotesis yang dirumuskan adalah sebagai berikut:

H4: Tipe kepribadian kombinasi NT berpengaruh terhadap kemampuan auditor dalam mendeteksi kecurangan.

\section{METODE PENELITIAN}

\section{Definisi Operasional Variabel dan Pengukurannya}

Model penelitian disajikan pada Gambar 1 . Pengalaman audit (EXP) merupakan suatu proses pembelajaran dan penambahan perkembangan potensi bertingkah laku baik dari pendidikan formal maupun non formal atau bisa juga diartikan sebagai suatu proses yang membawa seseorang kepada suatu pola tingkah laku yang lebih tinggi (Bawono dan Singgih, 2011). Pengalaman diukur dari berapa lama seorang auditor telah bekerja. Apabila semakin lama, maka dianggap auditor tersebut berpengalaman.

Tipe kepribadian (TYPE) NT adalah kepribadian dari individu yang memiliki kecendongan untuk memahami sesuatu dengan intuisi, khususnya terkait suatu keadaan yang dihadapinya. Individu dengan kepribadian NT akan mencoba untuk memahami makna atau lambang, hubungan serta pola-pola yang ada, dan kemungkinankemungkinan lainnya, lebih dari sekedar apa yang telah ditangkap melalui panca indra (Myers sebagaimana dikuti Noviyanti, 2008). Variabel tiperibadian NT akan diukur dengan dummy, dimana auditor yang memiliki tipe kepribadian NT akan diberi skor 1, sedang yang lain 0 .

Skeptisme profesional adalah sikap perilaku (attitude) yang sarat pertanyaan dalam benak (quetining mind), waspada (being alert) pada keadaan-keadaan yang mengindikasi kemungkinan salah saji karena kesalahan (error) atau kecurangan (fraud) dan penilaian yang kritis (critical 
assessment) terhadap bukti (Tuanakotta, 2013). Skeptisme profesional (SP) diukur dari pertanyaan-pertanyaan mengenai suatu sikap yang akan dilakukan terhadap suatu kondisi yang dikembangkan oleh Nasution (2012). Skala yang digunakan adalah skala likert.

Sedangkan pada variabel dependen yaitu kemampuan mendeteksi kecurangan yaitu kemampuan untuk mengenali dan mengidentifikasi gejala-gejala kecurangan (fraud symptoms) yang dikembangkan oleh Fullerton dan Durtschi (2004) dan dimodifikasi oleh Nasution (2012) yang terdiri dari gejala kecurangan terkait dengan lingkungan perusahaan (corporate environment) dan gejala kecurangan terkait catatan keuangan dan praktek akuntansi (financial records and accounting practice). Skala yang digunakan adalah skala likert.

Dalam penelitian ini terdapat empat variabel independen dan satu variabel dependen. Skala yang akan digunakan adalah skala Likert yang diolah terlebih dahulu diolah menggunakan Rasch Model. Dengan demikian data yang akan diolah menggunakan SPSS merupakan data yang sifatnya ukuran linier.

\section{Lokasi dan Sampel Penelitian}

Penelitian ini dilakukan di Kantor Akuntan Publik (KAP) Yogyakarta dan Surakarta pada tahun 2015 dengan subyek penelitian adalah auditor yang bekerja pada beberapa KAP di kota tersebut. Pemilihan sampel di Yogyakarta dan Surakarta didasarkan pada dua alasan, pertama karena auditor yang diteliti berasal dari KAP kecil. Penelitian terdahulu kebanyakan meneliti isu sejenis dengan menggunakan sampel auditor dari KAP madia dan besar (big four), sehingga hasil- hasil penelitian terdahulu masih dominan berlaku pada konteks auditor di kantor KAP madia dan besar, dan belum tentu berlaku pada auditor yang bekerja pada KAP kecil. Kedua, tempat penelitian (kota Yogyakarta dan Surakarta) masuk dalam kawasan Jawa bagian tengah dimana auditornya mayoritas berasal dari suku Jawa beretnis Jawa halus yang memiliki adab keraton yang masih kuat.

Dalam pandangan Hofstede (2011), kuatnya adab keraton di Jawa bagian tengah ini memunculkan apa yang disebut dengan power distance yang selanjutnya mempengaruhi sikap orang suku Jawa bagian tengah menjadi lebih sungkan dan menjaga keharmonisan (Prayudi dan Basuki, 2014). Sikap semacam ini berkemungkinan memunculkan rendahnya skeptisme profesional auditor karena auditor dari suku Jawa halus lebih mengedepankan keharmonisan hubungan dibandingkan tuntutan profesionalisme.

Metode penentuan sampel menggunakan purposive sample dengan kriteria sampel adalah auditor yang telah bekerja minimal satu tahun dan pernah melakukan tugas audit minimal tiga kali. Daftar KAP yang dijadikan obyek penelitian disajikan pada Tabel 1.

\section{Data dan Sumber Data}

Data dari penelitian ini adalah hasil jawaban kuesioner yang diisi oleh sampel secara langsung. Pengumpulan data dilakukan dengan metode survey, yakni dengan cara mengirimkan kuesioner penelitian kepada sampel dan mengumpulkannya secara langsung dengan cara mendatangi ke kantor dimana sampel bertugas (Hartono dan Abdillah, 2008). Kuesioner yang diberikan menggunakan jenis pertanyaan tertutup dan terbuka pada beberapa informasi yang diperlukan.

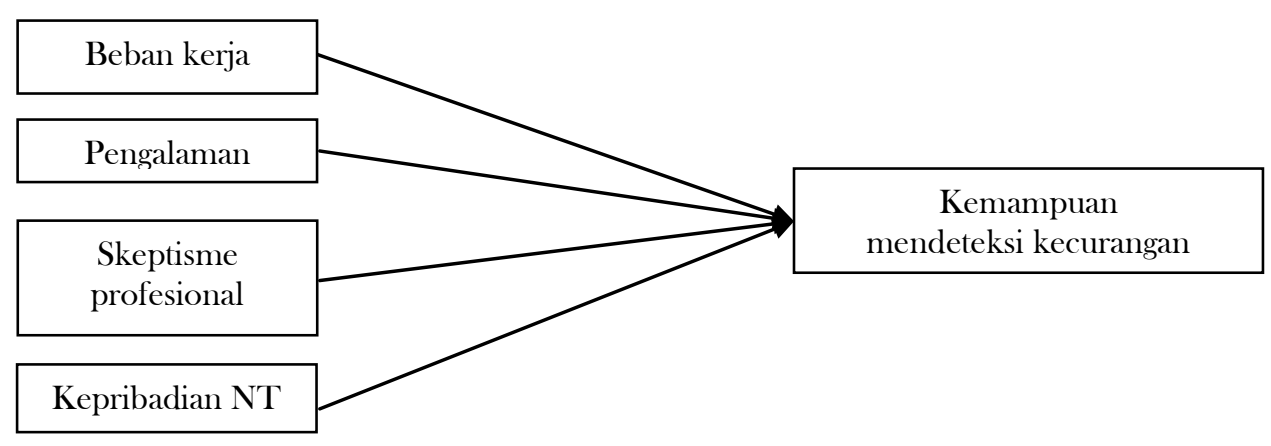

Gambar 1. Model Penelitian 
Skala yang digunakan adalah skala linear dengan interval yang sama. Interval yang sama diperoleh dengan menggunakan Rasch model. Beban kerja (WL) pada penelitian ini adalah banyaknya jumlah klien yang harus ditangani oleh seorang auditor atau terbatasnya waktu auditor untuk melakukan proses audit (Nasution, 2012). Beban kerja diukur dengan rata-rata jumlah pekerjaan yang dilakukan auditor selama satu tahun. Apabila jumlah pekerjaan yang dilakukan rendah atau sedikit maka beban kerja yang diterima oleh auditor adalah ringan.

\section{Teknik Analisis Data}

Analisis data penelitian dilakukan dengan Rasch model. Rasch model merupakan alat analisis yang dapat menguji validitas dan reliabilitas data serta menguji kesesuaian person dan item secara simultan. Rasch model mampu memberikan skala linear dengan interval yang sama, melakukan prediksi terhadap data yang hilang, memberikan estimasi yang tepat, mendeteksi ketidaktepatan model, serta menghasilkan pengukuran yang replicable (Suminto, 2013).

Keunggulan Rasch model dibanding model lain adalah kemampuan melakukan prediksi terhadap data yang hilang, yang didasarkan pada pola respon yang sistematis. Model lain memperlakukan data yang hilang dengan nilai nol, sedang Rasch menghasilkan kemungkinan terbaik dari data yang hilang. Sehingga dengan Rasch model membuat data yang diolah sebagai data yang lengkap (Suminto, 2013). Pemodelan Rasch yang diperkenalkan George Rasch pada sekitar tahun 1960 merupakan model yang populer menghasilkan data pengukuran. Data pengukuran pada penelitian ilmu sosial yang didapat ini diukur menggunakan penerapan sistem pengukuran yang standar digunakan dalam ilmu eksakta. Selain itu dalam pengukuran obyektif, pengukuran harus memenuhi lima syarat, yaitu: (1) Memberikan ukuran yang linear; (2) Mengatasi data yang hilang; (3) Melakukan proses estimasi yang tepat; (4) Menemukan yang tidak tepat (misfit) dan tidak umum (outliners); dan (5) Memberikan instrumen pengukuran yang independen dari parameter yang diteliti (Suminto, 2013).

Rasch Model dengan aplikasi Ministep akan menghasilkan beberapa pilihan untuk analisis data. Hasil statistik Ministep akan menunjukkan banyak data person dan aitem yang diolah, nilai rata-rata logit untuk person, nilai reliabilitas untuk person dan aitem, nilai cronbach alpha, dan error standar aitem. Nilai reliabilitas untuk person dan aitem memiliki ketentuan: Jika nilai reliabilitas $<0.67$ maka dikatakan rendah; Jika nilai reliabilitas 0,670.80 maka dikatakan cukup; Jika nilai reliabilitas 0,81-0.90 maka dikatakan bagus; Jika nilai reliabilitas 0,91-0.94 maka dikatakan bagus sekali; Jika nilai reliabilitas >0,94 maka dikatakan istimewa. Sedangkan untuk nilai cronbach alpha memiliki ketentuan sebagai berikut: Jika nilai cronbach alpha < 0.5 maka dikatakan buruk; Jika nilai cronbach alpha 0.5-0.6 maka dikatakan jelek; Jika nilai cronbach alpha 0.6-0.7 maka dikatakan cukup; Jika nilai cronbach alpha 0.7-0.8 maka dikatakan bagus; Jika nilai cronbach alpha $>0.8$ maka dikatakan bagus sekali (Suminto, 2013).

Selain itu, Rasch ini akan menghasilkan informasi berupa aitem yang sesuai dan tidak sesuai dengan data yang kita butuhkan, sehingga akan diketahui aitem mana yang harus direvisi atau dibuang. Ketentuan dari aitem tersebut adalah sebagai berikut: Nilai Outfit Mean Square (MNSQ) yang diterima: $0.5<\mathrm{MNSQ}<1.5$; Nilai Outfit Z-Standard (ZSTD) yang diterima: 2,0<ZSTD<2.0; Nilai Point Measure Correlation (Pt Mean Corr): $0.4<\mathrm{Pt}$ Measure Corr $<0.85$ (Suminto, 2013).

\section{Pengujian Hipotesis}

Setelah data diolah menggunakan Ministep dan memenuhi ketentuan dan syarat yang telah ditentukan, maka data siap diolah menggunakan aplikasi SPSS. Hasil pengolahan Ministep dapat membantu dalam pengambilan keputusan atas data yang diolah, apakah data perlu direvisi, dibuang, atau menambah atau memperluas data yang diperlukan.

Pengujian hipotesis dilakukan dengan uji nilai t. Simpulan bahwa terdapat hubungan pengaruh dari variabel independen terhadap variabel dependen dapat dibuat jika nilai probabilitas atau nilai signifikan (nilai Sig.) <alpha 0,05 . Selain itu, digunakan pula uji nilai $\mathbf{R}$ suquared untuk mengetahui kualitas model penelitian dalam menjelaskan hubungan variabelvariabel yang diteliti (Nazaruddin dan Basuki, 2015). Pada penelitian ini uji hubungan antar variabel dilakukan dengan teknik regresi berganda pada SPSS dan Microsoft Excel. Pada SPSS digunakan regresi berganda dengan fungsi sebagaimana berikut ini:

$\mathrm{Y}=\mathrm{a}+\beta 1 \mathrm{X} 1+\beta 2 \mathrm{X} 2+\beta 3 \mathrm{X} 3+\beta 4 \mathrm{X} 4+\mathrm{e}$ 
Tabel 1. Daftar Kantor Akuntan Publik Sampel Penelitian

\begin{tabular}{|c|c|c|c|}
\hline No. & Nama KAP & Ijin KAP & Alamat \\
\hline 1 & KAP Drs. Bismar, Muntalib,\& Yunus & 183/KM. 1/2008 & $\begin{array}{l}\text { Jl. Soka No.24, Baciro, } \\
\text { Yogyakarta } 55225\end{array}$ \\
\hline 2 & KAP Drs. Henry \& Sugeng (Pusat) & 1365/KM. 1/2009 & $\begin{array}{l}\text { Jl. Gajah Mada No.22, } \\
\text { Yogyakarta } 55112\end{array}$ \\
\hline 3 & KAP Drs. Suhartati \& rekan (CAB) & KEP-172/KM. 6/ 2003 & $\begin{array}{l}\text { Perumahan Nogotirto I No. } \\
\text { 11, Nogotirto, Gamping, } \\
\text { Sleman, Yogyakarta } 55292\end{array}$ \\
\hline 4 & KAP Busroni \& Payamta (CAB) & KEP-014/KM. 6/ 2004 & $\begin{array}{l}\text { Jl. Ir. Soetami No. } 25 \text {, } \\
\text { Surakarta } 57126\end{array}$ \\
\hline 5 & KAP Wartono & KEP-292/KM. 6/ 2003 & $\begin{array}{l}\text { Jl. K. H. Samanhudi } \\
\text { No.121, Surakarta } 57147\end{array}$ \\
\hline
\end{tabular}

\section{HASIL DAN PEMBAHASAN}

Kuesioner yang didistribusikan ke Kantor Akuntan Publik (KAP) sebanyak 105 kuesioner yang diantar langsung ke KAP. Kuesioner yang mendapatkan respon sebanyak 65 kuesioner. Data yang dapat diolah 63 kuesioner dan 2 kuesioner dikeluarkan dari sampel karena tidak memenuhi ketentuan purposive sampling.

Deskripsi responden menyajikan identitas responden yang meliputi: jenis kelamin, pendidikan terakhir, jabatan, lama waktu menjabat, dan lama bekerja menjadi auditor. Namun, identitas responden tidak lengkap. Identitas yang dapat identifikasi adalah jenis kelamin, pendidikan terakhir dan lama bekerja menjadi auditor. Berikut identitas responden yang disajikan ke dalam Tabel 2.

Tabel 2. Identitas Responden

\begin{tabular}{lcc}
\hline Kriteria & $\begin{array}{c}\text { Jumlah } \\
\text { responden }\end{array}$ & Prosentase \\
\hline Jenis Kelamin & 19 & $30,2 \%$ \\
$\begin{array}{l}\text { Perempuan } \\
\text { Laki-laki }\end{array}$ & 44 & $69,8 \%$ \\
$\begin{array}{l}\text { Pendidikan terakhir } \\
\text { DIII }\end{array}$ & - & \\
S1 & 27 & $42,8 \%$ \\
S2 bekerja & - & 0 \\
S3 & 2 & $3,2 \%$ \\
Tidak menjawab & 34 & $54 \%$ \\
Lama & & \\
menjadi auditor & 2 & $3,2 \%$ \\
Lebih dari 15 tahun & 9 & $14,3 \%$ \\
10-15 tahun & 29 & $46 \%$ \\
6-10 tahun & 23 & $36,5 \%$ \\
1-5 tahun dari 1 & - & 0 \\
Kurang dari & & \\
tahun & &
\end{tabular}

Pengujian rasch model yang menggunakan aplikasi Ministep menghasilkan informasi berupa nilai reliabilitas untuk person atau responden, item atau butir, dan secara keseluruhan. Selain itu, rasch modelmenghasilkan nilai kesesuaian person atau item secara rinci sehingga memudahkan untuk mengetahui person yang memiliki kemampuan tinggi dan rendah. Rasch juga memudahkan untuk mengetahui butir soal yang mudah dijawab dengan soal yang sulit untuk dijawab responden (lihat Tabel 3).

\section{Tabel 3. Ringkasan Statistik dari Skeptisme Profesional}

\begin{tabular}{lc}
\hline Kriteria & Hasil \\
\hline Person Reliability & 0,6 \\
Person Measure & 3,05 \\
Item Reliability & 0,85 \\
Item Measure & 0,00 \\
S.E of Item Mean & 0,21 \\
Cronbach Alpha & 0,8 \\
\hline
\end{tabular}

Tabel 3 menunjukkan bahwa nilai person reliability variabel skeptisme profesional sebesar $0,6<0,67$ yang berarti reliabilitas person atau responden tergolong lemah sedangkan nilai item reliability sebesar 0,85 berada di rentang 0,81-0,90 yang berarti reliabilitas item atau butir pertanyaan tergolong bagus. Rendahnya nilai person reliability ini mengindikasikan dua kemungkinan; pertama, jawaban responden mengenai skeptisme profesional auditor memiliki keragaman (varians) yang cukup tinggi sehingga hasil olah statistik menilainya sebagai adanya kemungkinan pemahaman responden atas pertanyaan instrumen tidak seragam. Artinya, ada kemungkinan instrumen kurang mudah dipahami secara general sehingga dinilai memiliki reliabilitas yang lemah oleh statistik. Kemungkinan kedua adalah, jawaban skeptisme profesional auditor memang menjurus pada keseragaman yang rendah yang juga mengindikasikan beragamnya skeptisme profesional auditor secara riil. Hal ini didukung dari hasil item relibality yang tinggi $(0,85)$ yang artinya 
Tabel 4. Person Measure dari Skeptisme Profesional

\begin{tabular}{|c|c|c|c|c|c|}
\hline \multirow{2}{*}{ Person } & \multirow{2}{*}{ Measure } & \multicolumn{2}{|c|}{ Outfit } & \multirow{2}{*}{ PT-Measure Corr } & \multirow{2}{*}{ Kesesuaian } \\
\hline & & MNSQ & ZSTD & & \\
\hline 12 & 5,61 & \multicolumn{2}{|c|}{ maximum measure } & 0 & Tidak Sesuai \\
\hline 13 & 5,61 & \multicolumn{2}{|c|}{ maximum measure } & () & Tidak Sesuai \\
\hline 14 & 5,61 & \multicolumn{2}{|c|}{ maximum measure } & 0 & Tidak Sesuai \\
\hline 15 & 5,61 & \multicolumn{2}{|c|}{ maximum measure } & 0 & Tidak Sesuai \\
\hline 29 & 5,61 & \multicolumn{2}{|c|}{ maximum measure } & 0 & Tidak Sesuai \\
\hline 33 & 5,61 & \multicolumn{2}{|c|}{ maximum measure } & 0 & Tidak Sesuai \\
\hline 42 & 5,61 & \multicolumn{2}{|c|}{ maximum measure } & 0 & Tidak Sesuai \\
\hline 44 & 5,61 & \multicolumn{2}{|c|}{ maximum measure } & () & Tidak Sesuai \\
\hline 49 & 5,61 & \multicolumn{2}{|c|}{ maximum measure } & 0 & Tidak Sesuai \\
\hline 52 & 5,61 & \multicolumn{2}{|c|}{ maximum measure } & 0 & Tidak Sesuai \\
\hline 56 & 5,61 & \multicolumn{2}{|c|}{ maximum measure } & 0 & Tidak Sesuai \\
\hline 3 & 4,37 & 0,8 & 0,3 & 0,15 & Sesuai \\
\hline 4 & 4,37 & 0,44 & $-0,1$ & 0,36 & Sesuai \\
\hline 11 & 4,37 & 0,58 & 0 & 0,26 & Sesuai \\
\hline 16 & 4,37 & 0,58 & 0 & 0,26 & Sesuai \\
\hline 51 & 4,37 & 0,8 & 0,3 & 0,15 & Sesuai \\
\hline 6 & 3,61 & 0,58 & $-0,3$ & 0,35 & Sesuai \\
\hline 17 & 3,61 & 0,48 & $-0,4$ & 0,45 & Sesuai \\
\hline 50 & 3,61 & 0,55 & $-0,3$ & 0,4 & Sesuai \\
\hline 5 & 3,15 & 0,63 & $-0,4$ & 0,37 & Sesuai \\
\hline 20 & 3,15 & 1,35 & 0,7 & 0,22 & Sesuai \\
\hline 24 & 3,15 & 0,56 & $-0,5$ & 0,45 & Sesuai \\
\hline 25 & 3,15 & 0,56 & $-0,5$ & 0,45 & Sesuai \\
\hline 26 & 3,15 & 0,86 & 0 & 0,2 & Sesuai \\
\hline 60 & 3,15 & 0,96 & 0,2 & 0,16 & Sesuai \\
\hline 61 & 3,15 & 0,56 & $-0,5$ & 0,45 & Sesuai \\
\hline 63 & 3,15 & 1,37 & 0,7 & 0,07 & Sesuai \\
\hline 8 & 2,8 & 1,03 & 0,2 & 0,28 & Sesuai \\
\hline 59 & 2,8 & 1,08 & 0,3 & 0,09 & Sesuai \\
\hline 1 & 2,51 & 0,73 & $-0,4$ & 0,34 & Sesuai \\
\hline 7 & 2,51 & 0,82 & $-0,2$ & 0,51 & Sesuai \\
\hline 10 & 2,51 & 0,78 & $-0,3$ & 0,54 & Sesuai \\
\hline 18 & 2,51 & 1,01 & 0,2 & 0,12 & Sesuai \\
\hline 34 & 2,51 & 0,59 & $-0,7$ & 0,49 & Sesuai \\
\hline 40 & 2,51 & 0,6 & $-0,7$ & 0,47 & Sesuai \\
\hline 41 & 2,51 & 1,63 & 1,2 & 0,17 & Sesuai \\
\hline 45 & 2,51 & 0,76 & $-0,3$ & 0,28 & Sesuai \\
\hline 55 & 2,51 & 1,21 & 0,6 & 0,24 & Sesuai \\
\hline 58 & 2,51 & 0,86 & $-0,1$ & 0,45 & Sesuai \\
\hline 27 & 2,27 & 1,3 & 0,7 & 0,17 & Sesuai \\
\hline 62 & 2,27 & 0,98 & 0,1 & 0,16 & Sesuai \\
\hline 28 & 2,06 & 0,78 & $-0,4$ & 0,27 & Sesuai \\
\hline 32 & 2,06 & 0,73 & $-0,5$ & 0,32 & Sesuai \\
\hline 48 & 2,06 & 0,79 & $-0,3$ & 0,49 & Sesuai \\
\hline 57 & 2,06 & 1,96 & 1,8 & $-0,13$ & Tidak Sesuai \\
\hline 19 & 1,86 & 0,81 & $-0,3$ & 0,33 & Sesuai \\
\hline 21 & 1,86 & 0,83 & $-0,3$ & 0,51 & Sesuai \\
\hline 22 & 1,86 & 1,12 & 0,4 & $-0,05$ & Sesuai \\
\hline 54 & 1,86 & 1,11 & 0,4 & 0,19 & Sesuai \\
\hline 2 & 1,68 & 1,2 & 0,6 & 0,33 & Sesuai \\
\hline 9 & 1,52 & 1,55 & 1,3 & 0,52 & Sesuai \\
\hline 31 & 1,52 & 0,69 & $-0,7$ & 0,17 & Sesuai \\
\hline 35 & 1,52 & 0,85 & $-0,3$ & 0,66 & Sesuai \\
\hline 46 & 1,52 & 1,32 & 0,9 & 0,57 & Sesuai \\
\hline 47 & 1,52 & 1,01 & 0,2 & 0,33 & Sesuai \\
\hline
\end{tabular}


Tabel 4. Person Measure dari Skeptisme Profesional

\begin{tabular}{cccccc}
\hline \multirow{2}{*}{ Person } & \multirow{2}{*}{ Measure } & \multicolumn{2}{c}{ Outfit } & \multirow{2}{*}{ PT-Measure Corr } & \multirow{2}{*}{ Kesesuaian } \\
\cline { 3 - 4 } & & MNSQ & ZSTD & & \\
\hline 23 & 1,22 & 1,03 & 0,2 & 0,41 & Sesuai \\
37 & 1,22 & 1,51 & 1,3 & 0,47 & Sesuai \\
43 & 1,08 & 0,99 & 0,1 & 0,34 & Sesuai \\
39 & 0,94 & 1,13 & 0,5 & 0,63 & Sesuai \\
38 & 0,82 & 0,37 & $-2,3$ & 0 & Tidak Sesuai \\
53 & 0,82 & 0,84 & $-0,3$ & 0,58 & Sesuai \\
30 & 0,57 & 1,47 & 1,3 & 0,3 & Sesuai \\
\hline
\end{tabular}

Tabel 5. Item Measure dari Skeptisme Profesional

\begin{tabular}{|c|c|c|c|c|}
\hline \multirow{2}{*}{ Item } & \multicolumn{2}{|c|}{ Outfit } & \multirow{2}{*}{ PT-Measure Corr } & \multirow{2}{*}{ Kesesuaian } \\
\hline & MNSQ & ZSTD & & \\
\hline 8 & 0,72 & $-1,2$ & 0,57 & Sesuai \\
\hline 11 & 1,41 & 1,6 & 0,36 & Tidak Sesuai \\
\hline 12 & 1,12 & 0,5 & 0,36 & Tidak Sesuai \\
\hline 6 & 0,92 & $-0,2$ & 0,48 & Sesuai \\
\hline 10 & 0,76 & $-0,9$ & 0,49 & Sesuai \\
\hline 3 & 1,40 & 1,4 & 0,23 & Tidak Sesuai \\
\hline 9 & 0,87 & $-0,4$ & 0,52 & Sesuai \\
\hline 14 & 0,77 & $-0,8$ & 0,62 & Sesuai \\
\hline 15 & 0,73 & $-0,8$ & 0,59 & Sesuai \\
\hline 13 & 1,04 & 0,2 & 0,32 & Tidak Sesuai \\
\hline 2 & 0,82 & $-0,4$ & 0,37 & Tidak Sesuai \\
\hline 4 & 0,68 & $-0,7$ & 0,41 & Sesuai \\
\hline 1 & 1,05 & 0,3 & 0,20 & Tidak Sesuai \\
\hline 5 & 0,50 & $-0,6$ & 0,36 & Tidak Sesuai \\
\hline 7 & 0,97 & 0,2 & 0,18 & Tidak Sesuai \\
\hline
\end{tabular}

tidak ada masalah pada reliabilitas item pertanyaan kuesioner penelitian. Dengan demikian, kemungkinan yang dapat diyakini oleh peneliti adalah kemungkinan kedua, yakni keseragaman tingkat skeptisme profesional auditor dari sampel penelitian relatif tinggi dan beragam.

Tabel 6. Ringkasan Statistik dari Kemampuan mendeteksi kecurangan

\begin{tabular}{lc}
\hline Kriteria & Hasil \\
\hline Person Reliability & 0,9 \\
Person Measure & 0,33 \\
S.E of Person Mean & 0,27 \\
Item Reliability & 0,98 \\
Item Measure & 0 \\
S.E of Item Mean & 0,56 \\
Cronbach Alpha & 0,91 \\
\hline
\end{tabular}

Selain itu, meskipun person reliability lemah, namun person measure $(3,05)$ bernilai lebih besar dari pada rata-rata item yaitu item measure 0,00 . Selanjutnya, nilai cronbach alpha juga berada direntang 0,7-0,8 yang artinya adalah data pada variabel skeptisme profesional bagus atau reliabel. Dengan demikian maka data tetap memiliki kela- yakan kualifikasi untuk dilanjutkan dalam pengujian hipotesis. Secara rinci, hasil pengujian variabel skeptisme profesional disajikan pada Tabel 4. Berdasarkan tabel 4 terdapat person yang tidak sesuai dengan model $0.5<\mathrm{MNSQ}<1.5$, 2,0<ZSTD<2.0, dan 0.4<Pt Measure Corr $<0.85$. terdapat juga person yang memiliki maximum measure. Data pada person tersebut tergolong data yang outliers atau misfit. Data yang memiliki maximum measure akan menurunkan kualitas sistem pengukuran, sehingga harus dibuang atau dikeluarkan dari sampel. Tabel 5 merupakan rincian kesesuaian butir-butir pertanyaan yang disajikan dalam kuesioner. Beberapa butir pertanyaan memiliki nilai Pt Measure Corr yang <0.4, sehingga harus dikeluarkan karena akan mempengaruhi pengukuran dan menurunkan kualitas data. Dari Tabel 6 juga dapat disimak bahwa nilai person reliability variabel kemampuan dalam mendeteksi kecurangan sebesar 0,9 berada di rentang 0,81-0,90 yang berarti reliabilitas person atau responden tergolong bagus sedangkan nilai item reliability sebesar $0,98>0,94$ yang berarti reliabilitas item atau butir pertanyaan tergolong 
istimewa. Person reliability yang tergolong bagus didukung person measure sebesar 0,33 menunjukkan kemampuan rata-rata person rata-rata di atas item yaitu item measure 0,00 . Nilai rata-rata eror standar item sebesar 0,56 dan nilai cronbach alpha sebesar 0,91. Nilai cronbach alpha sebesar $0,91>0,8$ menunjukkan bahwa data pada variabel kemampuan mendeteksi kecurangan sangat bagus atau reliabel.

Tabel 7. Person Measure dari Kemampuan Mendeteksi Kecurangan

\begin{tabular}{|c|c|c|c|c|c|}
\hline \multirow{2}{*}{ Person } & \multirow{2}{*}{ Measure } & \multicolumn{2}{|c|}{ Outfit } & \multirow[t]{2}{*}{ PT-Measure Corr } & \multirow{2}{*}{ Kesesuaian } \\
\hline & & MNSQ & ZSTD & & \\
\hline 1 & 2,5 & 0,75 & $-0,4$ & 0,93 & Sesuai \\
\hline 2 & 2,5 & 0,75 & $-0,4$ & 0,93 & Sesuai \\
\hline 3 & 2,5 & 0,75 & $-0,4$ & 0,93 & Sesuai \\
\hline 4 & 2,5 & 0,75 & $-0,4$ & 0,74 & Sesuai \\
\hline 5 & 2,5 & 0,75 & $-0,4$ & 0,74 & Sesuai \\
\hline 26 & 2,5 & 0,75 & $-0,4$ & 0,74 & Sesuai \\
\hline 27 & 2,5 & 0,75 & $-0,4$ & 0,93 & Sesuai \\
\hline 28 & 2,5 & 0,75 & $-0,4$ & 0,93 & Sesuai \\
\hline 29 & 2,5 & 0,75 & $-0,4$ & 0,74 & Sesuai \\
\hline 30 & 2,5 & 0,75 & $-0,4$ & 0,93 & Sesuai \\
\hline 41 & 2,5 & 0,75 & $-0,4$ & 0,74 & Sesuai \\
\hline 42 & 2,5 & 0,75 & $-0,4$ & 0,74 & Sesuai \\
\hline 43 & 2,5 & 0,75 & $-0,4$ & 0,93 & Sesuai \\
\hline 44 & 2,5 & 0,75 & $-0,4$ & 0,93 & Sesuai \\
\hline 45 & 2,5 & 0,75 & $-0,4$ & 0,93 & Sesuai \\
\hline 46 & 2,5 & 0,75 & $-0,4$ & 0,93 & Sesuai \\
\hline 47 & 2,5 & 0,75 & $-0,4$ & 0,93 & Sesuai \\
\hline 48 & 2,5 & 0,75 & $-0,4$ & 0,93 & Sesuai \\
\hline 49 & 2,5 & 0,75 & $-0,4$ & 0,74 & Sesuai \\
\hline 50 & 2,5 & 0,75 & $-0,4$ & 0,74 & Sesuai \\
\hline 59 & 2,5 & 0,75 & $-0,4$ & 0,74 & Sesuai \\
\hline 11 & 1,63 & 1,29 & 0,8 & 0,47 & Sesuai \\
\hline 21 & 1,63 & 1,29 & 0,8 & 0,47 & Sesuai \\
\hline 35 & 1,63 & 1,29 & 0,8 & 0,47 & Sesuai \\
\hline 53 & 1,63 & 1,29 & 0,8 & 0,47 & Sesuai \\
\hline 6 & 0,85 & 0,69 & $-0,8$ & 0,5 & Sesuai \\
\hline 13 & 0,85 & 0,72 & $-0,7$ & 0,83 & Sesuai \\
\hline 14 & 0,85 & 0,72 & $-0,7$ & 0,83 & Sesuai \\
\hline 16 & 0,85 & 0,69 & $-0,8$ & 0,5 & Sesuai \\
\hline 23 & 0,85 & 0,72 & $-0,7$ & 0,83 & Sesuai \\
\hline 25 & 0,85 & 0,72 & $-0,7$ & 0,83 & Sesuai \\
\hline 31 & 0,85 & 0,72 & $-0,7$ & 0,83 & Sesuai \\
\hline 32 & 0,85 & 0,72 & $-0,7$ & 0,83 & Sesuai \\
\hline 40 & 0,85 & 0,69 & $-0,8$ & 0,5 & Sesuai \\
\hline 54 & 0,85 & 0,72 & $-0,7$ & 0,83 & Sesuai \\
\hline 58 & 0,85 & 0,72 & $-0,7$ & 0,83 & Sesuai \\
\hline 60 & 0,85 & 0,69 & $-0,8$ & 0,5 & Sesuai \\
\hline 12 & 0,58 & 1,74 & 1,7 & 0,3 & Sesuai \\
\hline 22 & 0,58 & 1,74 & 1,7 & 0,3 & Sesuai \\
\hline 34 & 0,58 & 1,74 & 1,7 & 0,3 & Sesuai \\
\hline 57 & 0,58 & 1,74 & 1,7 & 0,3 & Sesuai \\
\hline 7 & $-1,03$ & 1,98 & 1,5 & 0,06 & Sesuai \\
\hline 17 & $-1,03$ & 1,98 & 1,5 & 0,06 & Sesuai \\
\hline 39 & $-1,03$ & 1,98 & 1,5 & 0,06 & Sesuai \\
\hline 55 & $-1,03$ & 1,98 & 1,5 & 0,06 & Sesuai \\
\hline 8 & $-1,92$ & 0,11 & -2 & 0,89 & Sesuai \\
\hline 15 & $-1,92$ & 3,41 & 2,4 & $-0,8$ & Tidak Sesuai \\
\hline 18 & $-1,92$ & 0,11 & $-0,2$ & 0,89 & Sesuai \\
\hline 24 & $-1,92$ & 3,41 & 2,4 & $-0,8$ & Tidak Sesuai \\
\hline 33 & $-1,92$ & 3,41 & 2,4 & $-0,8$ & Tidak Sesuai \\
\hline
\end{tabular}


Tabel 7. Person Measure dari Kemampuan Mendeteksi Kecurangan

\begin{tabular}{|c|c|c|c|c|c|}
\hline \multirow{2}{*}{ Person } & \multirow{2}{*}{ Measure } & \multicolumn{2}{|c|}{ Outfit } & \multirow[t]{2}{*}{ PT-Measure Corr } & \multirow{2}{*}{ Kesesuaian } \\
\hline & & MNSQ & ZSTD & & \\
\hline 38 & $-1,92$ & 0,11 & -2 & 0,89 & Sesuai \\
\hline 52 & $-1,92$ & 0,11 & -2 & 0,89 & Sesuai \\
\hline 61 & $-1,92$ & 3,41 & 2,4 & $-(0,08$ & Tidak Sesuai \\
\hline 9 & $-2,89$ & 0,43 & $-0,6$ & 0,67 & Sesuai \\
\hline 19 & $-2,89$ & 0,43 & $-0,6$ & 0,67 & Sesuai \\
\hline 37 & $-2,89$ & 0,43 & $-0,6$ & 0,67 & Sesuai \\
\hline 56 & $-2,89$ & 0,43 & $-0,6$ & 0,67 & Sesuai \\
\hline 62 & $-2,89$ & 0,43 & $-0,6$ & 0,67 & Sesuai \\
\hline 10 & $-3,36$ & 0,69 & 0 & 0,53 & Sesuai \\
\hline 20 & $-3,36$ & 0,69 & 0 & 0,53 & Sesuai \\
\hline 36 & $-3,36$ & 0,69 & () & 0,53 & Sesuai \\
\hline 51 & $-3,36$ & 0,69 & 0 & 0,53 & Sesuai \\
\hline 63 & $-3,36$ & 0,69 & 0 & 0,53 & Sesuai \\
\hline
\end{tabular}

Tabel 8. Item Measure dari Kemampuan Mendeteksi Kecurangan

\begin{tabular}{|c|c|c|c|c|}
\hline \multirow{2}{*}{ Item } & \multicolumn{2}{|c|}{ Outfit } & \multirow{2}{*}{ PT-Measure Corr } & \multirow{2}{*}{ Kesesuaian } \\
\hline & MNSQ & ZSTD & & \\
\hline 1 & 2,7 & 2,7 & 0,2 & Tidak Sesuai \\
\hline 2 & 0,41 & $-4,7$ & 0,9 & Tidak Sesuai \\
\hline 5 & 0,84 & -1 & 0,54 & Sesuai \\
\hline 3 & 1,38 & 2,1 & 0,84 & Tidak Sesuai \\
\hline 10 & 0,93 & $-0,3$ & 0,7 & Sesuai \\
\hline 8 & 0,9 & $-0,5$ & 0,71 & Sesuai \\
\hline 4 & 1,05 & 0,3 & 0,83 & Sesuai \\
\hline 7 & 0,94 & $-0,2$ & 0,79 & Sesuai \\
\hline 9 & 0,6 & $-2,2$ & 0,91 & Tidak Sesuai \\
\hline 6 & 0,41 & $-3,5$ & 0,91 & Tidak Sesuai \\
\hline
\end{tabular}

Berdasarkan Tabel 7 terdapat person yang tidak sesuai dengan model $0.5<\mathrm{MNSQ}<1.5$, 2,0<ZSTD<2.0, dan 0.4<Pt Measure Corr $<0.85$. Meskipun tidak seluruhnya memenuhi model yang ditentukan, tetapi memiliki nilai yang dapat ditoleransi dan tidak menurunkan kualitas sistem pengukuran. Person dengan nilai $\mathrm{MNSQ} \geq 2,0$ apabila dipertahankan berada di dalam sampel akan menurunkan kualitas sistem pengukuran. Data pada person tersebut juga tergolong data yang outliers atau misfit. Sehingga person pada nomor tersebut harus dibuang dari sampel.

Tabel 8 merupakan rincian kesesuaian butirbutir pertanyaan yang disajikan dalam kuesioner. Berdasarkan tabel tersebut, item pertanyaan sesuai dengan model $0.5<\mathrm{MNSQ}<1.5$, 2,0<ZSTD<2.0, dan $0.4<\mathrm{Pt}$ Measure Corr $<0.85$ adalah item nomor 1, 2, 3, 6, dan 9. Item tersebut harus dibuang atau dikeluarkan sehingga nomor pertanyaan yang sesuai adalah $4,5,7,8$, dan 10 . Berdasarkan hasil pengujian rasch ini, person dan item pada variabel skeptisme profesional dan kemampuan dalam mendeteksi kecurangan adalah reliabel yang dicerminkan dengan nilai cronbach alpha yang berada direntang 0,8-0,9.
Selain itu, didapatkan beberapa person tidak sesuai dengan model yang ditentukan sehingga perlu untuk dibuang atau dikeluarkan dari sampel. Person yang dikeluarkan dari sampel yaitu person nomor $12,13,14,15,24,29,33,38,36,42,44$, $49,52,56,57$, dan 61. Jumlah seluruh person yang dikeluarkan adalah 16 person sehingga jumlah person yang sesuai adalah 47 person. Delapan item pada variabel skeptisme profesional karena tidak sesuai dengan model yang ditentukan. Lima item pada variabel kemampuan dalam juga dikeluarkan dari data karena tidak sesuai dengan model yang ditentukan. Adapun data variabel skeptisme profesional yang telah diuji menggunakan rasch model disajikan pada Tabel 9.

\section{Statistik Deskriptif}

Statistik deskriptif menyajikan respon responden terhadap variabel beban kerja, pengalaman audit, skeptisme profesional, tipe kepribadian NT (Intuition dan Thinking), serta kemampuan auditor dalam mendeteksi kecurangan (lihat Tabel 10). 
Tabel 9. Person Entry dari Skeptisme Profesional dan Kemampuan Mendeteksi Kecurangan

\begin{tabular}{|c|c|c|c|c|c|}
\hline \multirow{2}{*}{ Person } & \multicolumn{2}{|c|}{ Measure } & \multirow{2}{*}{ Person } & \multicolumn{2}{|c|}{ Measure } \\
\hline & SP & FR & & SP & FR \\
\hline 1 & 3,04 & 3,40 & 31 & 1,60 & 1,63 \\
\hline 2 & 1,60 & 3,40 & 32 & 2,01 & 2,79 \\
\hline 3 & 5,20 & 3,40 & 33 & 0,90 & 3,40 \\
\hline 4 & 3,89 & 2,79 & 34 & 2,47 & 3,40 \\
\hline 5 & 3,04 & 2,79 & 35 & 1,24 & 3,40 \\
\hline 6 & 5,20 & 1,63 & 36 & 1,24 & 3,40 \\
\hline 7 & 3,89 & $-1,75$ & 37 & 1,24 & 3,40 \\
\hline 8 & 3,89 & $-1,75$ & 38 & 3,04 & 2,79 \\
\hline 9 & 2,47 & $-1,75$ & 39 & 5,02 & $-3,05$ \\
\hline 10 & 3,04 & $-3,05$ & 40 & 0,20 & 1,63 \\
\hline 11 & 5,20 & 1,63 & 41 & 1,60 & 2,21 \\
\hline 12 & 5,20 & 1,63 & 42 & 2,47 & $-1,75$ \\
\hline 13 & 3,89 & $-1,75$ & 43 & 3,89 & 2,21 \\
\hline 14 & 3,04 & $-1,75$ & 44 & 3,04 & 2,79 \\
\hline 15 & 2,01 & $-1,75$ & 45 & 5,20 & 1,63 \\
\hline 16 & 3,89 & $-3,05$ & 46 & 3,04 & $-1,75$ \\
\hline 17 & 2,47 & 1,63 & 47 & 3,89 & $-3,05$ \\
\hline 18 & 2,47 & 1,63 & & & \\
\hline 19 & 0,90 & 2,21 & & & \\
\hline 20 & 2,47 & $-2,80$ & & & \\
\hline 21 & 3,04 & 2,79 & & & \\
\hline 22 & 2,47 & 3,40 & & & \\
\hline 23 & 1,60 & 2,06 & & & \\
\hline 24 & $-0,25$ & 2,62 & & & \\
\hline 25 & 1,24 & 2,21 & & & \\
\hline 26 & 1,24 & 2,21 & & & \\
\hline 27 & 2,47 & 1,63 & & & \\
\hline 28 & 1,60 & 1,63 & & & \\
\hline 29 & 0,59 & $-1,75$ & & & \\
\hline 30 & $-0,51$ & $-1,75$ & & & \\
\hline
\end{tabular}

$\underline{\text { Tabel 10. Statistik Deskriptif }}$

\begin{tabular}{lccccc}
\hline & N & Maksimum & Minimum & Mean & Deviasi Standar \\
\hline Beban kerja (WL) & 47 & 4 & 2 & 2,617 & 0,570 \\
Pengalaman kerja (EXP) & 47 & 5 & 2 & 2,936 & 0,818 \\
Skeptisme profesional (SP) & 47 & 5,2 & $-0,51$ & 2,604 & 1,484 \\
Tipe kepribadian (TYPE) & 47 & 1 & 0 & 0,681 & 0,471 \\
Kemampuan mendeteksi kecurangan & 47 & 3,4 & $-3,05$ & 0,997 & 2,293 \\
(FR) & & & & \\
\hline
\end{tabular}

\section{Hasil Pengujian Hipotesis}

Sebelum dilakukan pengujian hipotesis, terlebih dahulu dilakukan uji asumsi klasik untuk mengetahui kelayakan data dalam uji hipotesis dengan teknik regresi (Nazaruddin dan Basuki, 2015). Dari hasil uji asumsi klasik, meliputi: uji normalitas, multikolinearitas dan heteroskidastisitas didapatkan simpulan bahwa data telah memenuhi uji asumsi klasik, sehingga pengujian dengan analisis regresi dapat dilakukan.
Model regresi linear berganda digunakan dalam penelitian ini untuk mengetahui pengaruh variabel-variabel beban kerja (WL), pengalaman audit (EXP), skeptisme profesional (SP), dan tipe kepribadian (TYPE) terhadap kemampuan auditor dalam mendeteksi kecurangan (FR). Digunakannya teknik analisis regresi linear berganda sesuai dengan kerangka penelitian dimana terdapat satu variabel dependen dan lebih dari satu variabel independen (Ghozali, 2011; Nazaruddin dan Basuki, 2015). 
Hasil pengujian hipotesis disajikan pada Tabel 11. Dari analisis regresi ditemukan variabel beban kerja tidak berpengaruh signifikan terhadap kemampuan auditor dalam mendeteksi kecurangan. Hasil penelitian ini tidak konsisten dengan Nasution (2012) serta Setiawan dan Fitriany (2011) yang menyatakan bahwa beban kerja berpengaruh negatif dan signifikan terhadap kemampuan auditor dalam mendeteksi kecurangan. Jika dilihat dari statistik deskriptif responden, sebanyak 29 responden merupakan responden dengan lama bekerja sebanyak 6-10 tahun, 9 responden dengan lama bekerja 10-15 tahun, dan 2 responden selama lebih dari 15 tahun. Jumlah responden yang berpengalaman sebanyak 40 responden. Hal ini diduga menjadi penyebab variabel beban kerja menjadi tidak berpengaruh. Kaitannya adalah karena pengalaman auditor dalam bekerja sudah cukup lama, maka seberapapun beban kerja yang ditanggung oleh auditor maka hal itu tidak mempengaruhi kemampuan auditor dalam mendeteksi kecurangan.

Dalam sudut pandangan teori perlaku yang direncanakan (planned behavior theory) sebagaimana yang dikemukakan Ajzen dan Fishbein (2005) seseorang dengan pengalaman yang banyak akan mampu mengatur sikap dalam berperilaku termasuk kaitannya dalam pengambilan keputusan membuat tindakan. Dalam konteks audit, penjelasan ini dinilai dapat mewakili, yakni ketika auditor memliki banyak pengalaman, maka akan terbentuk pola intuisi yang mapan di dalam kerangka berpikir auditor tersebut yang selanjutnya menggiring secara semi-otomatis kepada auditor dalam bersikap dan bertindak ketika menemukan suatu fenomena yang dinilai janggal. Namun demikian, apakah benar tidak berpengaruhnya beban kerja terhadap kemampuan mendeteksi kecurangan oleh auditor ini dipenga ruhi oleh faktor pengalaman, perlu kiranya hal tersebut diuji pada penelitian berikutnya.

Selanjutnya, pengalaman audit memiliki pengaruh positif dan signifikan terhadap kemampuan auditor dalam mendeteksi kecurangan. Hasil penelitian ini konsisten dengan penelitian Noviyani (2002), Tirta dan Sholihin (2004) dan Nasution (2012) yang menyatakan pengalaman audit berpengaruh positif dan signifikan terhadap kemampuan auditor dalam mendeteksi kecurangan. Semakin banyak pengalaman auditor, maka auditor tersebut akan memiliki pengetahuan yang lebih mengenai indikasi kecurangan, sehingga auditor yang bersangkutan akan mudah mengenali mana yang mengindikasi adanya kecurangan. Dalam sudut pandang teori perilaku yang direncanakan (planned behavior theory), auditor yang memiliki banyak pengalaman juga cenderung lebih tahu pola dalam kecurangan karena pernah menemukan atau mengatasi kasus serupa sebelumnya (Ajzen dan Fishbein, 2005). Wawasan yang lebih banyak juga akan mendorong auditor untuk lebih pandai dalam mencari cara bagaimana bersikap terhadap klien yang dihadapinya, ketika klien melakukan penyembunyian atas perilaku curang.

Berikutnya, penelitian ini menemukan bahwa skeptisme profesional tidak pengaruh signifikan

Tabel 11. Hasil Pengujian Hipotesis

\begin{tabular}{lccc}
\hline Variabel & B & P-Value & Kesimpulan \\
\hline WL & 0,357 & 0,131 & Tidak Berpengaruh \\
EXP & 0,472 & 0,000 & Berpengaruh \\
SP & $-0,093$ & 0,104 & Tidak Berpengaruh \\
TYPE & 3,869 & 0,000 & Berpengaruh \\
\hline Adjusted R2 & & & 0,944 \\
F Statistic & & & 194,004 \\
Prob (F-Statistic) & & & 0,000 \\
\hline
\end{tabular}

Keterangan :

FR: Kemampuan mendeteksi kecurangan

WL: Beban kerja

EXP : Pengalaman auditor

SP: $\quad$ Skeptisme Profesional

TYPE : Tipe kepribadian NT

Dari hasil perhitungan regresi diperoleh persamaan sebagai berikut:

$\mathrm{FR}=-3,715+0,472 \mathrm{EXP}+3,869 \mathrm{TYPE}$ 
terhadap kemampuan auditor dalam mendeteksi kecurangan. Hasil ini tidak konsisten dengan beberapa penelitian sebelumnya (Suraida, 2006; Noviyanti, 2008; Gusti dan Ali, 2008; Carpenter et al., 2011; Januarti, 2011; Nasution, 2012; Kushasyandita dan Januarti, 2012) yang menemukan skeptisme profesional berpengaruh positif dan signifikan terhadap kemampuan auditor dalam mendeteksi kecurangan. Namun, temuan ini sesuai dengan hipotesis yang dirumuskan dan menjadi salah satu temuan yang sangat menarik karena berbeda dengan temuan-temuan penelitian terdahulu. Dugaan kuat atas tidak berpengarunya skeptisme auditor terhadap kemampuan mendeteksi kecurangan auditor adalah karena karakteristik dari dalam diri auditor yang mayoritas dari etnis Jawa Halus, sebagaimana yang dipaparkan pada perumusan hipotesis. Menurut Hofstede (2001) masyarakat Jawa halus yang berada di Jawa bagian tengah (termasuk Yogyakarta) memiliki kecenderungan sikap pemalu, sungkan, ramah dan mempertahankan keharmonisan hubungan baik di depan orang lain. Akibatnya, ketika terdeteksi suatu kecurangan yang ada di lapangan saat audit dilakukan, auditor dari etnis Jawa halus bisa saja akan berupaya menghindari konflik dengan auditan, demi menjaga hubugan baik yang telah terjalin. Penghindaran konflik juga bisa jadi kembali terkait dengan fee audit KAP kecil. Maksudnya adalah, ketika konflik KAP kecil terjadi dengan kliennya, maka ada kemungkinan klien akan memutus kontrak penggunaan jasa pada KAP kecil. Hal ini tentu menjadi kerugian bagi KAP. Oleh karenanya, auditor dari KAP kecil akan menjalin hubungan baik dengan auditan guna keberlanjutan kontrak hubungan kerja.

Di samping itu, tidak berpengaruhya skeptisme profesional terhadap kemampuan auditor dalam mendeteksi kecurangan ini juga dapat dikaitkan dengan beberapa alasan, yakni; pertama, auditor memiliki tanggung jawab dan fungsi auditor yang independen, sehingga auditor akan berusaha memenuhi tanggung jawab dan fungsinya dengan lebih mengacu kepada standar audit dan cenderung mengabaikan sikap skeptisme profesional. Hal ini didukung dengan adanya standar audit yang berlaku di Indonesia PSA 02 SA seksi 110 mengenai tanggung jawab dan fungsi auditor independen. Dalam konteks penelitian ini, ditemukan adanya kecenderungan dari auditor untuk berupaya menyelesaikan tugas sesuai dengan aturan yang ada di PSA 02 SA seksi 110 ketimbang secara sungguh-sungguh mela- kukan pemeriksaan dengan tujuan pendeteksian kecurangan.

Jika dikaitkan pada isu fee audit KAP kecil (lokasi penelitian ini) yang tergolong lebih kecil dari KAP madia dan besar, maka hal ini menjadi sangat masuk akal. Pasalnya, auditor yang menjalankan pemeriksaan dengan fee yang relatif kecil cenderung akan mencari lebih banyak proyek (job). Akibatnya, demi mengejar target jadwal pemeriksaan yang banyak, maka auditor di KAP kecil akan cenderung melakukan audit dalam kurun waktu yang singkat. Namun, agar tidak melanggar kode etik auditor yang dapat memunculkan sanksi bagi KAP kecil tersebut, maka proses audit tetap harus dijalankan dengan mengacu pada standar audit yang disebutkan tadi. Dengan demikian, maka fenomena "kejar target" inilah yang besar kemungkinannya menjadikan auditor menurunkan skeptismenya dalam menjalankan pemeriksaan (audit).

Kedua, menurut Amiruddin dan Sundari (2012) kemampuan auditor dalam mendeteksi kecuragan bergantung pada kecanggihan pelaku kecurangan, frekuensi manipulasi, tingkat kolusi dan ukuran senioritas yang dilibatkan. Semakin tinggi tingkat kolusi dan semakin tinggi pula tingkat manajemen yang terlibat dalam kecurangan, maka semakin sulit pula untuk mendeteksi kecurangan oleh auditor. Auditor yang bekerja pada KAP kecil belum tentu meimiliki ragam pengalaman pendeteksian yang banyak, layaknya auditor dari KAP besar. Akibatnya, meskipun auditor dari KAP kecil memiliki pengalaman dalam mendeteksi kecurangan untuk beberapa kasus, tetapi mereka tidak memiliki cukup pengetahuan mengenai kecanggihan praktik kecurangan yang dilakukan oleh auditan untuk kasus tertentu, sehinga kecurangan yang didesain dengan sangat rapi tidak terduga oleh auditor. Tidak terduganya indikasi kecurangan dari auditan oleh auditor ini selanjutnya menjadikan skeptisme auditor tidak terpancing untuk meningkat dan memicu upaya untuk bekerja lebih keras dalam mendeteksi kecurangan.

Kemungkinan ketiga dari alasan tidak berpengaruhnya skeptisme professional auditor terhadap kemampuan mendeteksi kecurangan juga bisa jadi akibat adanya fiksasi persepsi auditor (Luft dan Shields, 2001; Dearman dan Shields, 2005). Maksudnya adalah, auditor cenderung menilai baik pada auditan yang notabene sudah beberapa kali diaudit dan mendapatkan opini bagus. Dampak selanjutnya adalah, auditor akan menga- 
lami penurunan skeptisme karena adanya fikasasi persepsi baik kepada auditan tadi.

Selanjutnya, penelitian ini juga menemukan bahwa tipe kepribadian NT berpengaruh signifikan terhadap kemampuan auditor dalam mendeteksi kecurangan. Hasil ini konsisten dengan penelitian Noviyanti (2008). Auditor dengan tipe kepribadian NT cenderung berperilaku obyektif, kritis dan menekankan pola, konteks, dan hubungan. Kemampuan dalam mendeteksi kecurangan memerlukan obyektivitas dan sikap yang kritis untuk sensitif terhadap kecurangan yang cenderung berpola dan saling berhubungan. Penelitian ini menjadi penguat validitas eksternal dari penelitian Noviyanti (2008) yang dilakukan dengan pendekatan eksperimen yang notabene kuat pada aspek validitas internal tetapi agak lemah dalam sisi validitas eksternal (Nahartyo, 2012). Berdasarkan temuan dari penelitian ini, maka implikasi pentingnya adalah, penting bagi kantor akuntan publik (KAP), khususnya yang berada di Yogyakarta dan Surakarta untuk mempertimbangkan aspek kepribadian dari calon auditor yang akan direkrut atau bergabung. Pemilihan auditor dengan tipe kepribadian NT akan dapat lebih memiliki kemampuan dalam mendeteksi kecurangan, yang selanjutnya akan banyak membantu KAP dalam pelaksanaan tugas audit yang dijalankan.

\section{SIMPULAN}

Penelitian ini bertujuan menguji pengaruh beban kerja, pengalaman, skeptisme profesional, dan tipe kepribadian NT terhadap kemampuan auditor dalam mendeteksi kecurangan. Penelitian ini dilakukan di KAP kecil yang ada di Yogyakarta dan Surakarta dengan pertimbangan masih jarangnya penelitian sejenis dilakukan pada konteks KAP kecil. Selain itu, penelitian ini juga menguji fenomena skeptisme KAP kecil dengan mengaitkannya dengan isu ketergantungan pada klien dan auditor dari etnis Jawa Halus (Jawa bagian Tengah).

Penelitian ini menemukan bahwa pengalaman auditor dan tipe kepribadian NT memiliki pengaruh positif dan signifikan terhadap kemampuan auditor dalam mendeteksi kecurangan. Semakin berpengalaman seorang auditor maka ia akan semakin mampu dalam mendeteksi kecurangan. Namun, beban kerja auditor dinilai tidak mempengaruhi auditor dalam mendeteksi kecurangan karena auditor dinilai sudah sangat terbiasa dengan situasi tingginya beban dan ritme kerja. Akan tetapi, temuan yang cukup mengejutkan adalah tidak berpengaruhnya skeptisme profesional auditor terhadap kemampuan dalam mendeteksi kecurangan. Beberapa spekulasi alasan mengenai tidak berpengaruhnya skeptisme terhadap kemampuan mendeteksi kecurangan ini dipaparkan di bagian pembahsan.

Implikasi dari hasil penelitian ini adalah penting bagi para auditor yang bekerja di Kantor Akuntan Publik (KAP) kecil untuk semakin meningkatkan jam terbang auditor muda (junior) agar dapat memiliki pengalaman yang cukup sehingga dapat memiliki kemampuan mendeteksi kecurangan yang baik. Jam terbang auditor juga akan meningkatkan penyesuaian diri auditor dalam menghadapi beban kerja yang banyak, sehingga hal itu tidak akan mengganggu kinerja auditor dalam mendeteksi kecurangan, sebagaimana yang ditunjukkan dari temuan penelitian ini. Selanjutnya, KAP kecil perlu mempertimbangkan aspek kepribadian dalam merekrut auditor baru yang mana dianjurkan untuk merekrut auditor dengan tipe kepribadian NT (Intitution-Thinking). Sebagaimana temuan penelitian ini, individu dengan tipe kepribadian NT memiliki karakter untuk selalu melakukan pertimbangan-pertimbangan yang teoritis dan ilmiah dalam membuat keputusan tertentu, khususnya dala pendeteksian kecurangan. Terakhir, berdasarkan argumentasi yang dapat dijadikan alasan atas tidak berpengarunya skeptisme profesional auditor terhadap kemampuan mendeteksi kecurangan, maka penting bagi KAP untuk mengingatkan penjagaan auditor kepada sikap skeptisme profesionalnya. Di samping itu, penting bagi KAP dan para auditor yang ada di dalamnya untuk senantiasa meningkatkan kapabilitas dalam mendeteksi kecurangan yang terjadi atau dilakukan secara sengaja dengan cara yang sistemik dan terstruktur.

Penelitian ini tentu memiliki berbagai keterbatasan yang selanjutnya menjadi masukkan bagi penelitian selanjutnya yang mengangkat tema sejenis. Pertama, lokasi penelitian ini hanya pada KAP dan para auditor di Yogyakarta dan Surakarta, sehingga kemampuan generalisasi hasil penelitian ini masih cukup lemah. Oleh karenanya penelitian selanjutnya perlu untuk memperluas ruang lingkup sampel penelitian agar dapat hasil penelitian dapat digeneralisasi secara lebih luas. Kedua, penelitian ini mengembangkan model kuesioner dengan pertanyaan dan penyataan, sehingga ada kemungkinan terjadi bias saat sampel menjawab kuesioner. Oleh karenanya, 
penelitian mendatang dianjurkan untuk mengembangkan kuesioner pada variabel skeptisme profesional dan kemampuan mendeteksi kecurangan dengan pemberian contoh kasus. Terakhir, penelitian dengan tema sejenis perlu dilakukan dengan pendekatan lain, seperti kualitatif atau triangulasi (riset campuran) agar menemukan temuan penelitian yang lebih konprehensif (Sofyani dan Akbar, 2013; 2015).

\section{DAFTAR PUSTAKA}

Ajzen, I. 1991. The theory of planned behavior. Organizational Behavior and Human Decision Processes, 50 (2), 179-211.

Ajzen, I dan M. Fishbein. 2005. The Influence of Attitudes on Behaviour. In B. Albarracin, T. Jhonson, dan M.P. Zanna (eds.). The Handbook of Attitudes. Mawah: Erlbaum.

Amiruddin dan Sundari. 2012. Fraud: Bagaimana mendeteksinya?. Working Paper, Universitas Hassanuddin Makasar.

Bawono, I. R. dan E. M. Singgih. 2010. FaktorFaktor Dalam Diri Auditor dan Kualitas Audit: Studi pada KAP 'Big Four'di Indonesia. Jurnal Akuntansi dan Auditing Indonesia, 14 (2).

Beasley, M. S., J. V. Carcello dan D. R. Hermanson. 2001. Top 10 Audit Deficiencies. Journal of Accountancy, 63-66.

Carpenter, T. D., C. Durtschi dan L. M. Gaynor. 2011. The Incremental Benefits of a Forensic Accounting Course on Skepticism and Fraud-Related Judgments. Issues in Accounting Education, 26 (1), 1-21.

Dearman, D. T. dan M. D. Shields. 2005. Avoiding Accounting Fixation: Determinants of Cognitive Adaptation to Differences in Accounting Method. Contemporary Accounting Research, 22 (2), 351384.

Fishbein, M. dan I. Ajzen. 1974. Attitudes towards objects as predictors of single and multiple behavioral criteria. Psychological Review, 81 (1), 59-74.

Fishbein, M., dan I. Ajzen. 1975. Belief, attitude, intention, and behavior: An introduction to theory and research. Reading: AddisonWesley.

Fullerton, R. dan C. Durtschi. 2004. The effect of profesional skepticism on the fraud detection skills of internal auditors. Available at SSRN 617062. Diakses Oktober 2016.
Gusti, M dan S. Ali. 2008. Hubungan skeptisme profesional auditor dan situasi audit, etika, pengalaman serta keahlian audit dengan ketepatan pemberian opini auditor oleh akuntan publik. Paper Diperesentasikan pada Simposium Nasional Akuntansi VIII, Padang.

Hartono, J. dan W. Abdillah. 2008. Pedoman Survei Kuesioner: Mengembangkan Kuesioner, Mengatasi Bias dan Meningkatkan Respon. Yogyakarta: Badan Penerbit Fakultas Ekonomika dan Bisnis Universitas Gadjah Mada.

Hofstede, G. H. dan G. Hofstede. 2001. Culture's consequences: Comparing values, behaviors, institutions and organizations across nations. Thousand Oaks, CA: Sage Publication Inc.

Imam, G. 2011. Aplikasi Analisis Multivariate dengan Program SPSS. . Semarang: Badan Penerbit Universitas Diponegoro.

Januarti, I. 2011. Analisis Pengaruh Pengalaman Auditor, Komitmen Profesional, Orientasi Etis dan Nilai Etika Organisasi terhadap persepsi \& Pertimbangan Etis. Paper Dipresentasikan pada Simposium Nasional Akuntansi XIV, Aceh.

Koroy, T. R. 2009. Pendeteksian Kecurangan (Fraud) Laporan Keuangan oleh Auditor Eksternal. Jurnal Akuntansi dan Keuangan, $10(1), 22$.

Kushasyandita, R. dan I. Januarti. (2012). Pengaruh Pengalaman, Keahlian, Situasi Audit, Etika, dan Gender Terhadap Ketepatan Pemberian Opini Auditor Melalui Skeptisme Profesional Auditor (Studi Kasus Pada KAP Big Four di Jakarta). Disertasi Doktoral, Universitas Diponegoro.

Luft, J. L. dan M. D. Shields. 2001. Why Does Fixation Persist? Experimental Evidence on The Judgment Performance Effects of Expensing Intangibles. The Accounting Review, 76 (4), 561-587.

Nahartyo, E. 2012. Desain dan Implementasi Riset Eksperimen. Yogyakarta: UPP STIM YKPN.

Nasution, H. 2012. Pengaruh Beban Kerja, Pengalaman Audit dan Tipe Kepribadian Terhadap Skeptisme Profesional dan Kemampuan Auditor dalam Mendeteksi Kecurangan. Disertasi Doktoral, Universitas Indonesia. 
Nazaruddin, I. dan A. T. Basuki. 2015. Analisis Statistik dengan SPSS. Yogyakarta: Penerbit LP3M UMY.

Noviyani, P. 2002. Pengaruh Pengalaman dan Pelatihan terhadap Struktur Pengetahuan Auditor tentang Kekeliruan. Paper Dipresentasikan pada Simposium Nasional Akuntansi V, Makassar.

Noviyanti, S. 2008. Skeptisme Profesional Auditor Dalam Mendeteksi Kecurangan. Jurnal Akuntansi dan Keuangan Indonesia, 5 (1), 102-125.

Petty, R. E., D.T. Wegener dan L. R. Fabrigar. 1997. Attitudes and Attitude Chang. Annual Review of Psychology, 48 (1), 609647.

Prayudi, M. A. dan H. Basuki. 2015. Hubungan Aspek Power, Penerapan Sistem Pengendalian Administratif, Akuntabilitas, dan Efisiensi Program Jaminan Kesehatan. Jurnal Akuntansi dan Keuangan Indonesia, 11 (1), 57-77.

Rahma, N. dan R. T. Yulianti. 2016. Pengaruh Pendidikan Berbasis Syariah dan Komitmen Religiusitas terhadap Perilaku Etis Individu dalm Pelaporan Keuangan: Sebuah Studi Eksperimen. Tesis, Universitas Islam Indonesia.

Sari, C. M. A. dan R. Rustiana. 2016. Pemetaan Penerapan Standar Audit Berbasis ISA Pada Kantor Akuntan Publik (KAP) di Daerah Istimewa Yogyakarta. MODUSJurnal Ekonomi dan Bisnis, 28 (1), 23-38.

Setiawan, L. dan F. Fitriany. 2011. Pengaruh workload dan spesialisasi auditor terhadap kualitas audit dengan kualitas komite audit sebagai variabel pemoderasi. Jurnal Akuntansi dan Keuangan Indonesia, 8 (1), 36-53.

Sofyani, H. dan R. Akbar. 2013. Hubungan Faktor Internal Institusi dan Implementasi Sistem Akuntabilitas Kinerja Instansi Pemerintah (SAKIP) di Pemerintah Daerah. Jurnal Akuntansi dan Keuangan Indonesia, 10 (2), 184-205.

Sofyani, H dan Y. D. Pramita. 2013. Otoritas Atasan, Retaliasi dan Locus Of Control Sebagai Faktor-Faktor yang Memengaruhi Perilaku Manipulasi Laporan Realisasi Anggaran. Jurnal Reviu Akuntansi dan Keuangan, 3 (2), 415-506.

Sofyani, H. dan R. Akbar. 2015. Hubungan Karakteristik Pegawai Pemerintah Daerah Dan Implementasi Sistem Pengukuran
Kinerja: Perspektif Ismorfisma Institusional. Jurnal Akuntansi \& Auditing Indonesia, 19 (2), 153-173.

Suminto, B. 2013. Aplikasi Model Rasch untuk Penelitian Ilmu-IImu Sosial. Cimahi: Trim Komunikata Publishing House.

Suraida, I. 2006. Pengaruh Etika, Kompetensi, Pengalaman Audit dan Risiko Audit terhadap Skeptisme Profesional Auditor dan Ketepatan Pemberian Opini Akuntan Publik. Sosiohumaniora, 7 (3), 186.

Tesser, A. 1993. The Importance of Heritability in Psychological Research: The Case of Attitudes. Psychological Review, 100 (1), 129.

Tirta, R. dan M. Sholihin. 2004. The Effects of Experience and TaskSpesific Knowledge On Auditors' Performance In Assessing A Fraud Case. Jurnal Akuntansi dan Auditing Indonesia, 8 (1), 1-21.

Tuanakotta, T. M. 2013. Audit Berbasis ISA (International Standards on Auditing). Jakarta: Salemba Empat. 